\title{
INVESTIGATION OF PLANT DESIGNS ON WATER SURFACES IN TERMS OF LANDSCAPE DESIGN
}

\section{Elif AKPINAR KÜLEKÇ I ${ }^{1 *}$}

${ }^{1 *}$ Atatürk University, Faculty of Architecture and Design, Landscape Architecture Department, Erzurum,Turkey;

"Corresponding author Elif AKPINAR KÜLEKÇI, e-mail: eakpinar@atauni.edu.tr;

Received July 2020; Accepted August 2020; Published September 2020;

DOI: https://doi.org/10.31407/ijees10.416

\begin{abstract}
Water has a very important place in garden design. Water creates different ecological living spaces with movement, light and sound, but gives people peace of mind by making them feel different emotions. It creates a different climate and perception in garden designs. Water gardens; waterfalls, creeks, fountains, cascades, garden ponds, ponds and ornamental pools are designed and applied. Environment can be created for aquatic plants and living organisms. Aquatic plants; colors, textures, forms, scents are the most attractive and eye-catching elements of water gardens. However, by using water and aquatic plants together in an environmental arrangement, the reflective feature of the water is emphasized, creating a colorful and sparkling atmosphere and improving the landscape quality. In this study, the use of water in landscaping studies is examined through design principles and examples, and the points to be considered for the use of water gardens are emphasized.
\end{abstract}

Keywords: Water gardens, aquatic plants, water and landscape, water and garden 